\title{
A Critical Review of English Teachers Education Programs
}

\author{
Dr. Sara Mohamed Naguib Mohamed \\ Dr. El-Sayed Mohamad Dadour \\ Dr. Jehan Mahmoud El-Bassuony
}

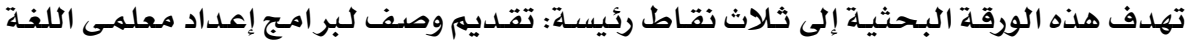

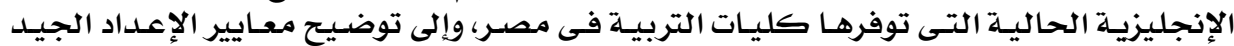

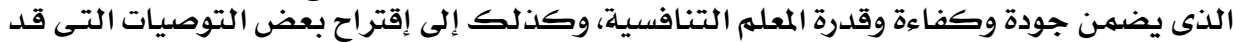

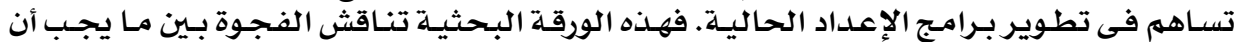

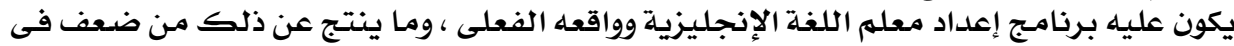

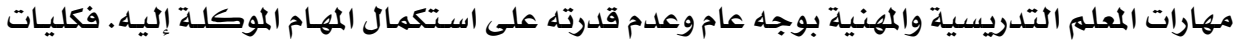

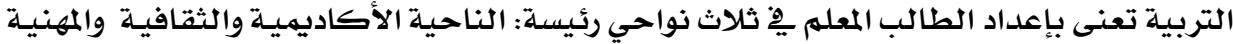

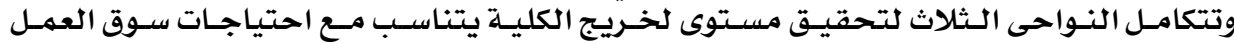

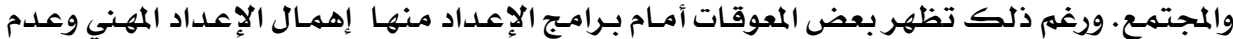

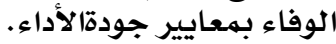

\section{Abstract :}

The aim of this paper is threefold: providing an overview on the kind of preparationEFLprospective teachers receive at Faculties of Education, describing the criteria of competent teacher education programs, and presenting some recommendations for improving teachereducationprograms in the Egyptian context.

Keywords: pre-service teacher preparation, English prospective teachers, Faculties of Education, criteria of competent education programs.

\section{1- Preparation of EFL Prospective Teachers}

Well preparation helps teachers face the difficulties of the profession and accomplish their responsibilities. Some obstacles may relate to the fact that teaching is one of the most stressful jobs in comparison to other occupations, for many reasons, as Adams(2001, p.223) stresses. One of these reasons is that the combination of all new ideas for better teaching have left the individual teacher feeling more accountable than before, yet more confused, and arguably less supported (Claxton, 1989). Other reasons for the difficulty and stress of the teaching profession include the inability to manage the learning environment, the undefined work roles and work overload, and the difficulty of applying the recommended teaching methods and practices. These previous reasons make teachers have little control over their occupational environment, planning, and decision-making

\section{9}


and lead them to refer to their teaching as stressful (Adams, 2001; Austin, Shah, and Muncer, 2005; Kyriacou, 2001). Such difficulties can be faced only if teachers are armed with well- preparation

In addition to the difficulties educators in general may face, teachers of foreign languages have other specific problems. For example, according to Mousavi (2007, p.33), EFL teachers are expected to empathize with learners, try to motivate them and encourage them to participate in classroom activities, and generally speaking, to help facilitate learning. However, in addition to all these roles, they also need to engage in many other tasks such as paperwork, evaluating students, preparing for the class, remaining up-to-date with their teaching area and preparing their teaching materials. At the same time, they might have positive or negative encounters, with parents, colleagues, administrative authorities and students, which can affect them psychologically. In addition, as Arnold (1999, p.6) highlights, teachers need to communicate and engage with students more than before and to care for their inner worlds. That is they are no longer looked at as the mere transferors of knowledge but as individuals who need to communicate.

To meet these responsibilities, there have been in the last two decades various calls for reform in teacher education programs to address the needs of students ( Dykes, Gilliam, Neel, and Everling , 2012, p.2). Consequently, many teacher education or preparation programs are being reviewed and reconstructed to meet the needs of the teacher of the 21st century.

According to Tedick (2005, p.7), Faculties of Education prepare student teachers in three main categories: academic, cultural, and professional. Academic preparation of student-teachers is concerned with the field of specialization that they will teach in the future. As for cultural preparation, it is related to general knowledge that reflects the characteristics of the age. Concerning professional preparation, it considers the necessary skills of the teaching profession that enable teachers to accomplish their mission as facilitators and guides.

Academic preparation is basically required; as Hill (2007, p.111) indicates high-quality preparation programs target a specific content-knowledge, subject-matter-specificinstruction, and

\section{0}


lor student learning. Also, Sawchuk (2012, p.2) agrees that teacher education standards should include content knowledge of the subject matter. Clearly, academic preparation of teachers in all fields of specializations consider mainly the content-knowledge of the subject matter. The same case with EFI future teachers, they have to be well-prepared in all English language skills.

Many EFL teacher preparation programs as stated by Shaila and Trudell (2010, p.4) focus on the academic preparation by adopting strategies for integrating the four skills. The task of integrating the speaking/listening and writing/reading classes was informed by Rebecca Oxford's image of a language class as a tapestry woven of different strands, where the primary skills of listening, speaking, reading, and writing are "one of the most crucial of these strands" (Oxford, 2001, p. 2). In addition, if these four skills are separated from one another, a language is taught; however, if they are integrated with each other, authentic communication is taught.

However, there are other skills that should be mastered by EFL teachers beside English language skills or rather, the academic skills. Abdel-Halim (2008), Ban Eric ( 2004), Caires and Alemida (2005), El-Dib ( 2003), El Okda (2005), Herman ( 2004), Mostafa (2005), and Saey (2006) agree that preparing EFL teachers is no more limited to improving the four main skills of English language. The process of improving these skills is related to the academic preparation. However, improving professional skills should necessarily receive similar attention. Otherwise, as concluded by Berry (2004) and Hebert and Worthy (2001), innovice teachers go through a reality shock as they come to realize that they are illprepared to meet the challenges they face when they first begin teaching.

Faculties of Education seek the actual application of the three preparation domains. Yet, there are identified problems. Despite the new approaches and teaching methods recommended in the most up-to-date researches, nothing actually changes in reality, that is in teacher preparation program. In this concern, Harwell (2003, p.1) states: " Formal teacher education has changed

\section{1}


remarkably little over the years, despite a steady stream of new educational theories, constant refinement and updating of degree plans at colleges of education. Likewise, teachers are doing in the classroom more or less the same thing they did a generation ago." According to Stigler, Gonzales, Kawanaka, Knoll, and Serrano (1999), regardless of the structure of the school or the culture of the community, teachers continue to use very traditional teaching methods.

As long as this is the case, education reform will continue to be largely ineffective. Thus, students are not expected to change what they do if teachers continue doing what they have always done. Teachers will change what they do only if they have highquality teacher professional development. When teachers are given the opportunity, via high-quality professional development, to learn new strategies for teaching to rigorous standards, they report changing their teaching in the classroom (Alexander, Heaviside, and Farris, 1998).

\section{2- Criteria of Competent Teacher Preparation Programs}

Because teachers are the most important single element of the educational system, as Hammond and Lieberman (2012, p. 2) state, significant emphasis is laid on teachers' preparation program. Abdel-Halim (2008, p.22) argue that teaching is seen as a craft which has a set of specialized and skilled physical techniques that teachers have to master during their education. In other words; to get teachers who are able to overcome the stress of the profession, preparation programs should provide student teachers with the necessary teaching skills especially, as Adams(2001, p.224) mentions, with the heavier responsibilities that EFL/ESL teachers along with teachers in other fields have nowadays. Clearly, preparation program is vitally important in covering the requirements or the expectations of the profession.

In teachers' preparation program, they are supposed to be wellprepared in all domains related to the teaching profession. Armour-Thomas, Clay, Domanico, Bruno, and Allen (1989) and Ferguson (1991) agree that the end result of all education reform should be student improvement. Yet, every reform initiative, if it is

\section{2}


to succeed, must begin with recognition of the importance of teachers in raising student performance. In other words, "student achievement is the product of formal study by educators" (Joyce and Showers, 2002, p. 3).

According to Loeb, Miller, and Strunk (2009, p.212), teacher education policies have the potential to greatly affect teachers' abilities to teach and, as a result, students' abilities to learn. Moreover, as El Dib(1993, p. 22) indicates, "teachers are what teacher preparation programs make them". Consequently, awareness of the reliabilities of teacher preparation is a prerequisite for any serious reform to take place. In this concern, El-bassuony (2011, p.2) confirms that a key element in any educational reform is the development of teacher professionalism since teachers are considered the main change agents in these reforms.

Betts, Andrew, and Rice (2003) stress that there is a strong relation between student outcome gains and teachers' undergraduate preparation. As teachers performance in teaching their specialization is influenced by pre-service academic and pedagogic preparation. Thus teachers perform significantly better if they are well prepared.

Harwell $(2003$, p.3) summarizes the problem in the following word: "education reform initiatives of the last twenty years have improved student performance very little. The main reason is that too little attention has been paid to what actually goes on in the classroom." Clearly to follow up several studies recommendations will benefit the preparation program. Among them is the variety in presentation.

Cross (1995, p.34) indicates that student teacher training program should have a variety in its presentation, just as there should be a variety of approaches in schools. The training modes might include: (a) The frontal mode, often called the teachercentered mode; (b) The experiential mode, in which trainees sample teacher and learner roles in peer teaching and micro teaching situations; (c) The workshop mode, which suits materials

\section{3}


production, lesson planning, textbook analysis, the design of tests, the development of visual aids, etc; (d) The group/pair work mode, which is most likely to involve most of the trainees for most of the time; and (e) The individualized mode, which allows trainees to take responsibility for their own learning.

In a related issue, Louden and Rohel $(2006$, p. 67) reveal that there are three main aspects through which one can judge student teachers development after finishing a course or training program. These aspects are: student teachers' initial conception of teaching and learning, understanding subject matter, and conceptions of learning to teach.

DED (2006, p. 13) adds that teachers should be prepared in seven major domains to be competent in the profession. The seven domains are: (a) social regard for learning; (b); learning environment; (c) diversity of learners; (d) curriculum; (e) planning, assessing, and reporting; (f) community linkages; and (g) personal growth and development. In that sense, Faculties of Education have to follow a systematic plan that guarantee preparing student teachers competently in the three major preparation domains. In the process of preparation all recommendations, aspects, new approaches, or models should be considered. Still, overcoming expected problems that might appear should not be neglected in order to prepare a teacher who is competent to the teaching profession.

Clearly, the solution for competent professional preparation is following a competent criteria depending on highly considered and recommended items. Harwell $(2003$, p.1) suggests that in order to improve student performance sufficient attention has to be paid to what actually goes on in the classroom.

The following four strategies, as mentioned by Shaila and Trudell(2010, pp.4-5), implement a successful four-skill integration for preparing EFL teachers: (a) Coordinate the curriculum for all classes; (b) Provide oral and written feedback on writing; (c) Maintain guided journals; (d) Institute peer review activities.

\section{4}


Focusing on important professional skills needed in the actual school setting is considered to be a crucial part of pre-service teacher education. According to Clift and Brady (2005, p.314); Loeb, Miller, and Strunk (2009, p.219) ; and Wilson, Floden, and Ferrini-Mundy (2002, p.192), nearly all preparation programs must include field experiences, such as student teaching, where skills may be learned and practiced. Thus, as concluded by many close observers of teacher education, field experiences exert an important influence on teacher preparation. Moreover, reflection should be taught and practiced. The ability to reflect is often, as Martin and Satterthwait (2000, P. 29) mention, a held up or an important attribute of an effective teacher. It is often stated for instance, that reflection is needed to transform a person from a novice to an expert.

In addition, active learning should be applied in teachers' preparation programs. According to Pepper, Blackwell, Monroe, and Coskey (2012, p. 2), preparation programs should stress the role of active learning. They elaborated that modeling active learning strategies has an influence on participants' later use of active learning strategies in their classrooms as practicing teachers. Another item to be reviewed is widening the circle of knowledge to include important conceptions. Wallace (1991, p. 133) states "Different conceptions of teaching have different implications for teacher education."

In this concern, Richards $(2005$, p.6) lists a number of conceptualizations that lead to different approaches to teacher education as follows: (a)Teacher learning as skill learning, considering teacher learning as the development of a range of different discrete skills; (b)Teacher learning as a cognitive process, emphasizing that teachers are active thinking decisionmakers who make instructional choices; (c)Teacher learning as personal construction, focusing on the belief that knowledge is actively constructed by learners and not passively received so on teachers' individual and personal contribution to learning and on the development of self-awareness and personal interpretation; and (d) Teacher learning as reflective practice, adopting the

\section{5}


notion of reflective teaching, that is teaching accompanied by collecting information on one's teaching as the basis for critical reflection.

Similarly, different educational philosophies should be reviewed. Pfister (2001, p.40) indicates that teachers can usefully learn from procedures drawn from different educational philosophies. This item is considered a vital solution to improve the teaching/learning process in general. Moreover, Maynard and Furlong (1994, p. 24 ) mention that student-teachers learn by modeling, thinking, studying, doing, and reflecting; by collaborating with other colleagues or teachers; by looking closely at their students and their work; and by sharing what they see. Consequently, competent professional preparation should take into consideration the application of such a variety.

Concerning the issue of the characteristics of sufficient competent professional preparation, Marzano, Pickering, and Pollock (2001, p.3) have identified nine research documented practices that improve student performance. These practices should also be applied to the improvement of teacher effectiveness via professional development and student teachers via early professional development. The following table summarizes the practices:

Table1. Categories of Instructional Strategies Affecting Student Achievement

\begin{tabular}{|l|l|}
\hline $\begin{array}{l}\text { Identifying similarities and } \\
\text { differences }\end{array}$ & Nonlinguistic representations \\
\hline Summarizing and note taking & Cooperative learning \\
\hline $\begin{array}{l}\text { Reinforcing effort and providing } \\
\text { recognition }\end{array}$ & $\begin{array}{l}\text { Setting objectives and providing } \\
\text { feedback }\end{array}$ \\
\hline Homework and practice & Generating and testing hypotheses \\
\hline $\begin{array}{l}\text { Questions, cues, and advance } \\
\text { organizers }\end{array}$ & \\
\hline
\end{tabular}

( Source: Marzano, Pickering, and Pollock, 2001, p.3)

Joyce and Showers $(2002$, p.5), in relation to promoting practices, mention that professional development should be designed around research-documented practices that enable educators to develop the skills necessary to implement what they

\section{6}


are learning. Thus, the choice of high cognitive practices has a remarkable influence on developing necessary professional skills for the teaching profession. Concerning recommended practices, Hammond and Lieberman (2012, p. 2) mention that competent teacher preparation programs should focus on the following practices: (1) emphasis on the preparation, induction, support and assessment of new teachers; (2 ) focus on teacher retention, teacher's professional knowledge and continuing professional development; and (3) curriculum change and critical policies.

The process of early and on-going professional development should also be based on sound educational practices such as contextual teaching. According to Harwell $(2003$, p.5) , contextual teaching presents useful information within familiar contexts. It is effective because it takes advantage of the fact that learning occurs best when learners process new information or knowledge in such a way that it makes sense to them in their own frames of reference. Contextual teaching is consistent with the way the mind naturally functions, as articulated, for example, in Caine, Caine, and Crowell's (1999) twelve principles of brain-based learning listed below:

1. The brain is a living system - a collection of parts that functions as a whole.

2. The brain/mind is social.

3. The search for meaning is innate.

4. The search for meaning occurs through patterning.

5. Emotions are critical for patterning.

6. Every brain simultaneously perceives and creates wholes and parts.

7. Learning involves both focused attention and peripheral perception.

8. Learning always involves conscious and unconscious processes.

9. We have at least two ways of organizing memory-static memory and dynamic memory.

\section{7}


10. Learning is developmental.

11. Complex learning is enhanced by challenge and inhibited by threat associated with a sense of helplessness or fatigue.

12. Every brain is uniquely organized.

Contextual teaching recognizes the fact that learning with understanding (as opposed to rote memorization) involves five processes known collectively (after their acronym) as the REACT strategies (CORD, 1999). These processes are:(a) Relating: Learning in the context of life experience. The process of relating abstract concepts to familiar ideas and situations utilizes the potential of the dynamic (as opposed to static) memory systems of our brains; (b)Experiencing: Learning in the context of exploration, discovery, and invention. Through experience students find meaning in learning abstract concepts. Recognition of the need to know encourages the brain to function at higher cognitive levels; (c) Applying: Applying concepts and information in useful contexts. Real-world applications encountered through mentorships, apprenticeships, or other work-based experiences provide contexts in which the usefulness of abstract concepts becomes evident; (d) Cooperating: Learning in the context of sharing, responding, and communicating with other learners. The brain is social. Learning occurs at much higher cognitive levels when learners interact; and (e)Transferring: Learning in the context of existing knowledge, using and building upon prior learning and experience. Learners are able to process new information when they can transfer what they already know to unfamiliar situations and problems.

The REACT strategies are not just about how students learn; rather, they are about teachers as well. For example, when professional development provides opportunities for participants to interact "cooperating" or serve as peer resources, what the participants learn in the professional development transfers into behaviors that are observable in the classroom (Birman, Desimone, Porter, and Garet, 2000, p.28). Professional development in which participants are given the opportunity to learn new classroom practices in the contexts within which those

\section{8}


practices will be used is far more effective than more traditional methods of professional development. In other words, contextual teaching via professional development can be as effective in changing teacher behaviors as contextual teaching in the classroom is in improving student behaviors.

According to Harwell (2003, p.7) , professional development that is designed to take full advantage of the potential of contextual teaching is characterized by the following:(a) It supports interaction among master teachers; (b) It takes place over an extended period of time (rather than in one-shot workshops and seminars); and (c) It provides opportunities for teachers to try new behaviors in safe environments and receive feedback from peers.

In another respect, the question of how student teachers are most appropriately prepared for their work as teachers is related to the three major models of professional teacher education. Each one highlights certain aspects of the process of learning to teach. According to Richards (2005, p.3) and Arends (2007, p.3), the models are: (a) The Craft Model: This model gives due value to the experiential aspect of professional development. The young trainee learns by imitating the expert's techniques and by following the expert's instruction and advice; (b) The Applied Science Model: This model gives due value to the scientific knowledge at the expense of the experiential aspects. The findings of scientific knowledge and experimentation are conveyed to the trainee by those who are experts in the relevant areas; and (c) The Reflective Model: This model, on contrary to the previous two models, gives due weight to scientific knowledge and experience of the profession.

The models distinguish two kinds of knowledge: Received knowledge ( related to language and language teaching) and Experiential knowledge (knowledge in-action by practice of the profession). Clearly, the models, known as the three major models of professional teacher education, should be taken into account in designing and modifying programs which target the preparation of a competent English teacher.

\section{9}


In brief, as Abdel-Halim (2008, p.24) concludes, training for the teaching profession generally has a theoretical content and also a period of practice within a professional setting. This combination of theory and practice within actual teaching setting promote the development of various professional skills. Christopher and Rigden (2002, P. 20) claim that a significant aim of professional education in addition to the acquisition of appropriate knowledge is the acquisition of a professional ideology: that ideology is about the desire to continue to learn in order to be the master of the professional knowledge upon which the practice is founded. In this respect Harwell (2003, p.4) states: "Professional development can succeed only in settings, or contexts, that support it." Thus, it is very important for the student teacher to practice the professional skills inside the classroom and the actual school setting.

\section{3- Recommendations for Improvement}

For the purpose of improving EFL pre-service teachers preparation program and improving the professionalism of EFL teachers, two major recommendations are suggested. First, stressing the relationship between professional development of inservice teachers and early professional development of prospective teachers. Second, concentrating on applicable considerations in teachers' preparation. Both recommendations are presented in detail within the following lines:

Stressing the Relationship Between Professional Development of In-service Teachers and Early Professional Development of Prospective teachers

It is clear that what student teachers learn in pre-service preparation directly affects their performance in the teaching profession. In other words, the professional skills that pre-service preparation program provides have a future effect on the profession development. For example, the ability to reflect on teaching practices and to apply action research, which are considered extremely important professional skills, are very difficult tasks for unprepared teachers. In this concern, Harmer (2007, p.12) mentions that teacher development relies on

\section{0}


reflection and evaluation for both students and tutors. Teachers can not reflect if they are not prepared on the complex process of the reflection practice. In addition to reflection, action research that influences professional development of teachers is considered difficult if not learned and practiced in earlier preparation. Such practices have a tremendous effect on the instruction process and the students' learning.

This last mentioned point illustrates that there is a basic similarity between professional development of teachers and early professional development of student-teachers : Both, as declared by Loeb, Miller, and Strunk (2009, p.213), are quests for improving student outcomes, and means to improve teaching. Developing teacher's skills is considered to be the most successful element in improving students' education. Harwell (2003, p.5) states: "For the most part, improving schools is ultimately about improving student performance. Contrary to popular thought, student achievement is not tied directly to higher expectations, more accountability, high-stakes tests, more time on task, newcurriculaand materials, more computers, or sophisticated lab equipment. Improved student performance is the result of improved teaching skills focused on average students."

The difference between the two lies in the target subject. Loeb, Miller, and Strunk (2009, p.214) explain that pre-service professional preparation policies begin with pre-service and licensure requirements that affect teachers before they enter the teaching force. In other words, the target subject is the studentteacher. Induction and mentoring policies aim to support teachers in their workforce and during their first years of teaching. Ongoing professional development programs, thus,serve more experienced teachers. Another major similarity is that pre-service education, sometimes called early professional development, accompanied by ongoing professional development comprise the formation process of competent teachers. According to Loeb, Miller, and Strunk (2009, p.215), there are four types of professional development related to the prescribed goals and example strategies which are shown in table 2.

\section{1}


Loeb, Miller, and Strunk (2009, p.215) illustrate that teachers begin their experiences with professional development when they are first enrolled in a pre-service education program. Most new teachers continue to enter the labor force through the traditional route of completing an undergraduate or a graduate teacher preparation program. Teacher education programs are significant means that can influence teachers' qualifications and educational opportunities. Because teacher education program is highly important, it should contain, as it is the case in in-service teacher programs, special focus on the professional skills required from the teacher or in other words: teacher professionalism. According to Danielson (2001), Darling-Hammond (2005), and Mpahla (2009), professionalism has been reported as one of the most important and evolving areas of concern for pre-service, novice, and in-service teachers.

Early professional development has an important advantage which deals with providing student teachers with leaders or instructors who help and/or guide them. According to Harwell (2003, p.4) , the most important ingredient of professional development is leaders. In other words, early professional development presented to student teachers during pre-service preparation provide instructors, monitors, supervisors, organizers, and leaders whose main focus is presenting help and guidance for the future teacher, who may not receive afterwards similar guided help.

Early professional development achieves another benefit which is changing teaching behaviors according to the situation because sometimes theoretical conceptions could not be applied practically. In relation to the flexibility of teaching performance Harwell (2003, p.4) states: " there is urgency of providing teacher professional development that changes teacher behaviors in ways that lead to improvement in student performance." It is clear that early, as well as ongoing professional development, has an influence on teaching performance. This influence is exercised in the countless decisions teachers make and actions they take.

\section{2}


Table 2. Professional Development Goals and Strategies

\begin{tabular}{|c|c|c|c|c|}
\hline Type & $\begin{array}{l}\text { Pre-service } \\
\text { Education }\end{array}$ & $\begin{array}{l}\text { Induction/ } \\
\text { Mentoring }\end{array}$ & $\begin{array}{l}\text { Ongoing } \\
\text { Professional } \\
\text { Development }\end{array}$ & $\begin{array}{l}\text { Evaluating and } \\
\text { Resulting } \\
\text { Professional } \\
\text { Development }\end{array}$ \\
\hline Goal & $\begin{array}{l}\text {-Prepare future } \\
\text { teachers to } \\
\text { teach public } \\
\text { school } \\
\text { students }\end{array}$ & $\begin{array}{l}\text {-Assist new } \\
\text { teachers in } \\
\text { transitioning } \\
\text { to classroom } \\
\text { practice }\end{array}$ & $\begin{array}{l}\text {-Keep teachers } \\
\text { abreast of new } \\
\text { curriculum and } \\
\text { policies }\end{array}$ & $\begin{array}{l}\text {-Assess } \\
\text { teachers' } \\
\text { continuing } \\
\text { professional } \\
\text { growth and } \\
\text { provide } \\
\text { ongoing } \\
\text { assistance }\end{array}$ \\
\hline $\begin{array}{l}\text { Strateg } \\
\text { ies }\end{array}$ & $\begin{array}{l}\text {-Quantity of } \\
\text { subject matter } \\
\text { coursework } \\
\text {-Field } \\
\text { experience and } \\
\text { student } \\
\text { teaching } \\
\text {-Methods of } \\
\text { holding } \\
\text { teacher } \\
\text { preparation } \\
\text { programs } \\
\text { accountable } \\
\text { for teacher } \\
\text { quality }\end{array}$ & $\begin{array}{l}\text {-Minimum } \\
\text { length of } \\
\text { participation } \\
\text {-Mentor } \\
\text { eligibility } \\
\text { criteria } \\
\text {-Resources } \\
\text { provided to } \\
\text { beginning } \\
\text { teachers } \\
\text {-Resources } \\
\text { provided to } \\
\text { mentors } \\
\text {-Completion } \\
\text { requirements } \\
\text {-Link to } \\
\text { licensure }\end{array}$ & $\begin{array}{l}\text {-Minimum } \\
\text { professional } \\
\text { development } \\
\text { credits/hours in } \\
\text { specific amounts } \\
\text { of time } \\
\text {-Approval of } \\
\text { professional } \\
\text { development } \\
\text { standards }\end{array}$ & $\begin{array}{l}\text {-Plan } \\
\text { requirements } \\
\text { (i.e., inclusion } \\
\text { of student } \\
\text { performance) } \\
\text {-Frequency of } \\
\text { evaluations } \\
\text {-Actions } \\
\text { following } \\
\text { unsatisfactory } \\
\text { review } \\
\text {-Evaluator }\end{array}$ \\
\hline
\end{tabular}

( Source: Loeb, Miller, and Strunk , 2009, p. 215).

What increase the importance of early professional development are the various problems ongoing professional development face. These problems limit its possibility and effectiveness. According to Hill(2007, p.113), effective ongoing professional development programs usually require large time commitments and are linked to the district's or school's instructional goals, curriculum, and materials. Most professional development programs do not share these features. On the contrary, these problems to a great extent are settled in early professional development.

Finally, early professional development shares the well-known advantages of ongoing professional development which are, as

\section{3}


listed by Harwell (2003, p.3), (a) refocusing attention on the classroom; (b) changing teachers' classroom behaviors in ways that lead to improvement in student performance; (c) giving participating individuals opportunities to practice what they learn over relatively extended periods of time; and (d) providing an ideal environment for interaction among participants. Clearly, as recommended by El-bassuony (2011, p.34), early professional development or what is known as pre-service teachers programs should be improved to prepare EFL teachers for life-long professional development through their teaching career.

\section{Concentrating on Applicable Considerations in Teachers' Preparation:}

There is a contradiction between what preparation should include to outcome a competent EFL teacher and what is actually presented in Faculties of Education preparation programs. As mentioned earlier, such preparation programs should include an activatedearlyprofessional development preparation accompanied by the taken-for granted academic and cultural preparation. Moreover, there are some applicable considerations to be taken into account in carrying out the preparation program. These considerations as recommended in this paper include the following:

1. Teacher preparation programs should adopt a variety of professional development strategies to outcome competent teachers.

2. The practicum that prospective teachers go through must guarantee a strong connection between the faculty and its representatives and the school and its administrators.

3. The purpose of practicum should be providing the opportunity for prospective teachers to practice all the roles in-service teachers are expected to perform, of course the first step in this process will be acknowledging such roles with the help of professionals.

4. More time should be provided for practice in the real school setting, once a week duration may be insufficient specially with the load of theoretical study .

\section{4}


5. The concept of professionalism and professional skills may receive more focus on teachers education programs.

6. The schools that proved to be more successful and cooperative should be chosen for pre-service teachers practicum, such schools are expected to appreciate professional activities which increase prospective teachers' motivation.

7. University regulations ought to be modified to present fair distribution of time and focus for the professional dimension of preparation.

8. Available communication between pre-service and in-service teachers must be encouraged for better awareness of the job challenges.

9. Reflective practices have to be well-identified for both inservice teachers and prospective teachers.

10. Self-assessment and peer assessment should be referred to in the process of evaluating teachers at the end of practicum.

11. Faculty representatives and Ministry of Education inspectors can coordinate their instructions to avoid any expected contradiction.

12. The proper supervision approach is to be adopted during training with all its learner-centered principles.

13. Other out-class tasks accomplished can be announced and rewarded to stress their importance .

14. Opportunities for self-improvement have to be well-identified for continuous following up of new teaching strategies, techniques, trends, problems, and creative innovations.

15. Programs in the field of teachers' professional development are to be implemented by Faculties of Education for a serious change in the competency of outcomes.

\section{4- Conclusion}

There is a gap in teacher's education programs offered by Faculties of Education, concerning what it really is and what it should be. Prospective teachers typically experience conflicts

\section{5}


between their ideas of teaching and learning and their experiences in practice. These conflicts reflect a serious problem in teachers' preparation program which is the lack of a competent professional preparation. Actually, teachers must have preparation opportunities and acquire sufficient skills to teach students via the highest standards. This cannot be done if teachers have not got the minimum level of the required professional skills. Following a systematic preparation that caters for all aspects of professionalism is the suggested solution to achieve any desired progress.

\section{References}

- Abdel-Halim, S. (2008). The Effect of Using Some Professional Development Strategies on Improving the Teaching Performance of English Language Student Teacher at the Faculty of Education, Helwan University in the light of Pre- Service Teacher Standards. Unpublished doctoral dissertation, Faculty of Education, Helwan university.

- Adams, E.(2001). A Proposed Causal Model of Vocational Teacher Stress. Journal of Vocational Education and Training, 53, (2), 223246.

- Alexander, D.; Heaviside, S.; \& Farris, E. (1998). Status of Education Reform in Public Elementary and Secondary Schools: Teachers' Perspectives. U.S. Department of Education, National Center for Education Statistics. Washington, D.C.: U.S. Government Printing Office.

- Arends, I. (2007). Learning to Teach . Mc Graw- Hill, New York, USA.

- Armour-Thomas, E.; Clay, C.; Domanico, R.; Bruno, K.; \& Allen, B. (1989). An outlier study of elementary and middle schools in New York City: Final Report. New York: New York City Board of Education.

- Arnold, J.(1999). Affect in Language Learning.Cambridge: Cambridge University Press.

- Austin, V.; Shah, S. ; \& Muncer, S. (2005). Teacher Stress and Coping Strategies Used to reduce Stress. Occupational Therapy International, 12, (2), 63-80. 
- BanEric, J. (2004). The Professional Context for Student Teacher Learning: Instructional Coaching Conversations. EdD. Indian University (0093). DAI, 66-04A, 1322.

- Berry, B. (2004). Recruiting and Retaining "Highly Qualified Teachers" for Hard-to-staff Schools. NASSP Bulletin, 88, (638), 527.

- Betts, J. , Andrew, C., \& Rice, L. (2003). Determinants of Student Achievement: New evidence from San Diego. San Diego: Public Policy Institute of California.

- Birman, B.; Desimone, L., Porter, A.; \& Garet, M. (2000). Designing Professional Development That Works. Educational Leadership, 57, (8), 28-33.

- Caine, G.; Caine, R.; \& Crowell, S. (1999). Mindshifts: A BrainCompatible Process for Professional Development and the Renewal of Education. Tucson, Arizona: Zephyr Press.

- Caires, S. \& Alemedia, S. (2005). Teaching Practice in Initial Teacher Education its Impact on Student Teachers' Professional Skills and Development. Journal of Education for Teaching , 31, (2), 111- 120.

- Christopher, I. \& Rigden, D. (2002). Improving Teacher Quality. American School Board Journal ,189, (4), 20-37 .

- Claxton, G. (1989). Being A Teacher: A Positive Approach to Change and Stress. London: Cassell.

- Clift, R. \& Brady, p.(2005). Research on methods courses and field experiences. In Studying teacher education: The report of the AERA Panel on Research and Teacher Education, edited by M. CochranSmith and K. Zeichner, pp. 309-424. Mahwah, NJ:Erlbaum.

- CORD : Center for Occupational Research and Development (1999). Teaching science contextually. Waco, Tx: CORD Communications.

- Cross, D. (1995). Language Teacher Preparation in Developing Countries: Structuring Pre-service Teacher Training Programs. Forum, 33 , (4), 34-39.

- Danielson, C. (2001). New Trends in Teacher Evaluation. Educational Leadership, 58, (5), 12-15

- Darling-Hammond, L. (2005). Teaching as a Profession: Lessons in Teacher Preparation and Professional Development. Phi Delta Kappan, 87, (3), 237-240. 
- DED: Department of Education (2006). National Competency-based Teacher Standards(NCBTS) A Professional Development Guide for Filipino Teachers . Republic of the Philippines: Department of Education.

- Dykes, O., Gilliam, B., Neel, J., \& Everling, K. (2012). Peeking inside Pandora's Box: One University's Journey into the Redesign of Teacher Educator Preparation. (ERIC Document Reproduction Service No. EJ978290).

- El-bassuony, J. (2011). Using Collaborative Action Research and Facebook to Develop EFL Pre-service Teachers' Professionalism in the Light of STEPS Standards. Studies in Curriculum and Instruction, 176, 1-48.

- El-Dib, M. (1993). Teaching Practice Imprisonment or Empowerment. CDELT Proceedings 13th National symposium on ELT. Feb 1992. Ain Shams University.

- El- Dib, M. (2003). Effects of an Action. Research Program on Prospective Teachers' Action Research Skills, Teacher Efficacy and Reflective Thinking. Egypt TESOL Journal, 2, (1).

- El-Okda, M. (2005). Evaluating an EFL WEBCT supported practicum.Educational Science Journal, Educational research institute, 10 .

- Ferguson, R. (1991). Paying for Public Education: New Evidence on How and Why Money Matters. Harvard Journal of Legislation, 28.

- Hammond, L. \& Lieberman, A. (2012). Teacher Education around the World: Changing Policies and Practices. Teacher Quality and School Development. (ERIC Document Reproduction Service No. ED530535).

- Harmer, J. (2007). The Practice of English Language Teaching (4th Edition). Longman Handbooks for Language Teachers.

- Harwell, S. (2003). Teacher Professional Development: It's Not an Event, It's a Process. CORD.

- Heber, E. \& Worthy, T. (2001). Does the First Year of Teaching Have to Be a Bad One? A Case Study of Success. Teaching and Teacher Education, 17, 897-911.

- Herman, G. (2004). North Dakota STUDENT Teacher Performance Based on the INTASC Model Standards and the Qualifications of Cooperating Teachers. Published Doctoral Dissertation, University of North Dakota. DAI, 65-08A, 2955.

\section{8}


- Hill, H. (2007). Learning in The Teaching Workforce. Future of Children, $17,(1), 111-28$.

- Joyce, B. \& Showers, B. (2002). Student Achievement Through Staff Development. Alexandria, Virginia: Association for Supervision and Curriculum Development. (ASCD).

- Kyriacou, C. (2001). Teacher Stress: Directions for Future Research. Educational Review , 53, (1), 27-35.

- Loeb, S., Miller, L., \& Strunk, K. (2009). The State Role in Teacher Professional Development and Education Throughout Teachers' Careers. American Education Finance Association, 212-228.

- Louden, W. \& Rohl, M. (2006) Too Many Instruction and not Enough Instruction: Perceptions of Preservice Teacher Preparation for Literacy Teaching in Australian Schools, Literacy, 40,66-78.

- Maynard. T. \& Furlong, J. (1994). Learning to Teach and Models of Mentoring in: D. Mcintyre. H. Hagger \& M.Wilkin (eds) Mentoring: Perspectives on School- Based Teacher Education. London: Kogen page.

- Martin, M. \& Satterthwait, D. (2000). The Disciplining of Preservice Teachers: Reflections on The Teaching of Reflective Teaching. Asia-Pacific Journal of Teacher Education, 28, (1), 28-40

- Marzano, R.; Pickering, D.; \& Pollock, J. (2001). Classroom Instruction That Works. Alexandria, Virginia: Association for Supervision and Curriculum Development.(ASCD).

- Mostafa, A. (2005). Exploring Pre and In-service EFL Teachers' Prevalent Levels of Reflection and Their Relationship to Teaching Performance. Ain Shames University: CDELT Occasional Papers, 39.

- Mousavi, E. (2007). Exploring Teacher Stress in Non-native and Native Teachers of EFL. ELTED, 10, 33-40

- Mpahla, N. (2009). An Investigation of Teachers' Perceptions of their Professionalism: A Case Study of Three Schools in the Butterworth Districts Eastern Cap. Unpublished masters' thesis, University of Fort Hare.

- Oxford, R. (2001). Integrated skills in the ESL/EFL classroom. Washington, DC: ERIC Clearing-house for Languages and Linguistics. ERIC Digest Reproduction Service ED456670.

\section{9}


- Pepper, K. , Blackwell, S. , Monroe, A. , \& Coskey, S. (2012). Transfer of Active Learning Strategies from the Teacher Education Classroom to PreK-12th Grade Classrooms. Current Issues in Education, 15, (3) , 1-23.

- Pfister, C. (2001). Developing ESP Vocabulary in the ESL Classrooms. In Burns, A. and Desilva, H. (Eds), Teacher voices (15-23). Sydney: National Center for English Language Teaching and Research.

- Richards, C. (2005). Professional Development of Language Teachers: Strategies for Teacher Learning. Cambridge: Cambridge University Press .

- Saey, M. (2006). The effect of Using Reflective Teaching on Developing EFL Student Teachers Teaching Skills. Unpublished master's thesis, Faculty of Education, Ain shams University.

- Sawchuk, S. (2012). Teacher-Prep Accreditor Appoints Panel to

- Set Performance Standards. (ERIC Document Reproduction Service No. EJ973154).

- Shaila, M., \& Trudell, B. (2010). From Passive Learners to Critical Thinkers: Preparing EFL Students for University Success. English Teaching Forum, (3), pp.2-9

- Stigler, J.; Gonzales, P.; Kawanaka, T.; Knoll, S.; \& Serrano, A. (1999). The TIMSS Videotape Classroom Study: Methods and Findings from an Exploratory Research Project on Eighth Grade Mathematics Instruction in Germany, Japan, and the United States. U.S. Department of Education, National Center for Education Statistics, NCES 99-074. Washington, D.C.: Government Printing Office.

- Tedick, D. (2005). Second Language Teacher Education International Perspectives.(ERIC Document Reproduction Service No. ED493807).

- Wallace, J. (1991). Training Foreign Language Teachers: A Reflective Approach. Cambridge: Cambridge University Press.

\section{潾溇潾潾}

\section{0}

